\title{
Diamond brecciation and annealing accompanying major metasomatism in eclogite xenoliths from the Sask Craton, Canada
}

\author{
Janina Czas ${ }^{1}$, Thomas Stachel ${ }^{1}$, D. Graham Pearson ${ }^{1}$, Richard A. Stern ${ }^{1}$, George H. \\ Read $^{2}$ \\ ${ }^{1}$ University of Alberta,Canada, jczas@ualberta.ca, tstachel@ualberta.ca, gdpearso@ualberta.ca, \\ rstern@ualberta.ca \\ ${ }^{2}$ Shore Gold Inc., Saskatoon, Canada, GRead@shoregold.com
}

\section{Introduction}

The Fort à la Corne (FALC) kimberlite field on the Archean Sask Craton (Collerson et al. 1990) is located in Western Canada within the Paleoproterozoic ( 1.8 Ga) Trans Hudson Orogen (THO; Rayner et al. 2005). During the THO, the Superior and the Churchill provinces were amalgamated, creating the North American Craton (Hoffman 1988). Diamonds have been discovered in $75 \%$ (Harvey et al. 2009) of the Cretaceous FALC kimberlites (Leckie et al. 1997), which sampled principally Trans Hudson age ( 1.9 Ga) lithospheric mantle beneath the Archean Sask Craton (Czas et al. submitted). In the absence of Archean lithospheric mantle, the FALC kimberlites provide an opportunity to study the composition of the lithospheric mantle, its metasomatic history and the mode of diamond formation of an unconventional diamond deposit.

\section{Samples and methods}

We studied eclogite xenoliths (diamondiferous $n=23$; diamond-free $n=30$ ) from FALC, including a unique sample crosscut by a diamond vein, for their major element (EPMA), trace element (LAICPMS), nitrogen, and stable isotope $\left(\delta^{18} \mathrm{O}, \delta^{13} \mathrm{C}, \delta^{15} \mathrm{~N}\right.$; SIMS $)$, compositions to assess their metasomatic history and possible relationships between metasomatism and diamond formation.

\section{Diamond-free eclogites}

All diamond-free eclogites consist of garnet and clinopyroxene, with accessory rutile or apatite being present in less than $10 \%$ of the samples. Clinopyroxene is omphacitic $(\mathrm{Na} /(\mathrm{Na}+\mathrm{Ca}) \geq 0.2$; Clark and Papike 1968), indicating an eclogitic rather than pyroxenitic assemblage. Even though the mineral chemistry spans a wide compositional range among xenoliths (garnet Mg\# varies from $33-82$ and
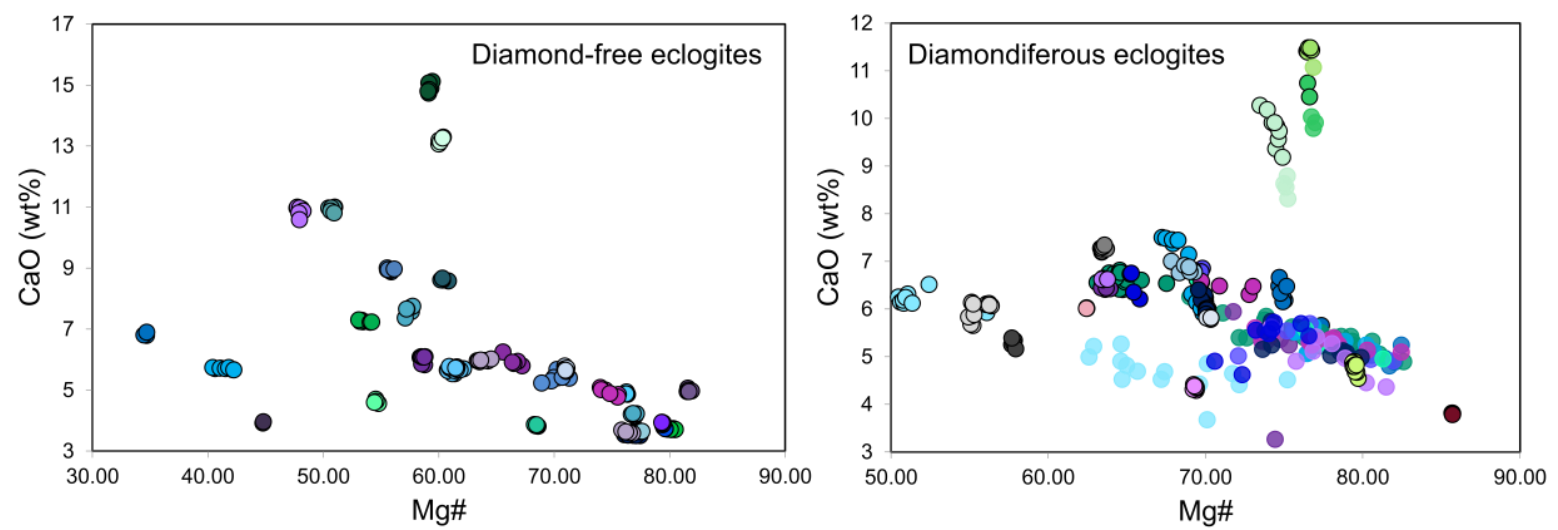

Figure 1: Major element variations in garnets from diamond-free and diamondiferous eclogites. At least two analytical spots were placed on each garnet grain, up to three grains were analysed per sample; colours indicate garnet analyses from individual samples. Garnet analyses from diamond free eclogites show a broad range, yet intra-sample variants are small. Garnets associated with diamonds often show significant variations within xenoliths and have been plotted as unaltered remnants (black rims) and metasomatised garnet (coloured rims). 
$\mathrm{CaO}$ content from $3.5-15.1 \mathrm{wt} \%$ ), it is typically homogenous within samples (Figure 1), with the exception of spongy-textured, jadeite-poor clinopyroxene related to partial melting and metasomatism (Carswell 1975; Su et al. 2011) that occurs in thin veins and rims surrounding relict omphacite. Garnet oxygen isotope compositions show a broad range from $\delta^{18} \mathrm{O}=+3.6 \pm 0.3 \%$ o to $+7.9 \pm 0.3 \%$. Temperatures calculated from Mg-Fe exchange between garnet and clinopyroxene (Krogh 1988) and projected onto the Sask Craton geotherm $\left(\sim 38 \mathrm{~mW} / \mathrm{m}^{2}\right.$ reference geotherm of Hasterok and Chapman 2011) range widely, from 740 to $1300{ }^{\circ} \mathrm{C}$, indicating the presence of eclogite through most of the lithospheric mantle.

\section{Diamondiferous eclogites}

Clinopyroxene is commonly absent in the small diamondiferous microxenoliths and garnet often represents the only identified silicate mineral. Compositionally, the garnets from diamondiferous eclogites have high $\mathrm{Mg \#} \mathrm{(50} \mathrm{to} \mathrm{86)} \mathrm{and} \mathrm{low} \mathrm{to} \mathrm{moderate} \mathrm{CaO}$ contents (3.3 to $11.5 \mathrm{wt} \%$ ). Temperatures (Krogh 1988) are restricted to higher values $\left(1180-1390{ }^{\circ} \mathrm{C}\right)$, indicating a deep derivation. The majority of garnets exhibit complex irregular textures in back-scattered electron (BSE) images (Figure 2A), corresponding to large variations in $\mathrm{Mg \#}$ (up to 25; Figure 1) and $\mathrm{CaO}$ content (up to $3.1 \mathrm{wt} \%$ ). Similar but less pronounced trends of increasing pyrope content have been reported for rims around eclogitic garnet and were attributed to late stage kimberlite infiltration. This prominent melt-metasomatic overprint is also reflected in LREE enrichment in the garnets of up to one order of magnitude within one sample and a shift in $\delta^{18} \mathrm{O}$ dominantly towards mantle-like $(+5.4$ to $+5.7 \%$; Ickert et al. 2013) compositions, showing that intense mantle metasomatism may
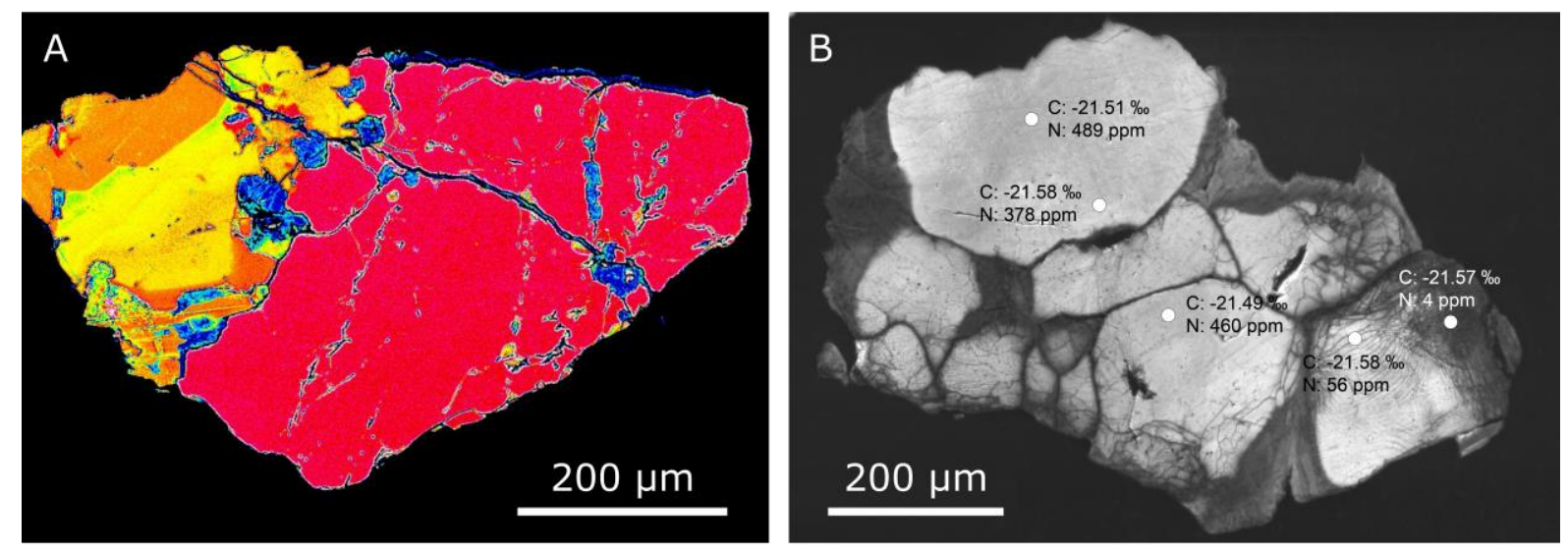

Figure 2: A. Backscattered-electron image showing intra-grain chemical variability within a single garnet from a diamondiferous eclogite. Mg\# varies between 51 (read area) and 71 (yellow area). B. Cathodoluminescence image of a brecciated diamond (primary diamond light grey) with secondary low-N diamond in annealed fractures (dark grey). Spot analyses of carbon isotope values and $\mathrm{N}$ concentrations are indicated.

homogenise oxygen isotope compositions rather than diversify them (cf Huang et al. 2012). Cathodoluminescence (CL) imaging of diamonds within intensely metasomatised FALC eclogite xenoliths reveals complex internal textures such as irregular thin bands and rims, exhibiting very low $\mathrm{N}$ abundances (Figure 2B). These unusual textures appear to represent diamond brecciation followed by annealing. The very close agreement in carbon isotopic composition between original nitrogen-rich diamonds and secondary nitrogen-poor fracture fillings and overgrowths suggests that annealing was based on carbon already present in the rock, involving, for instance, a diamond dissolution - reprecipitation process.

\section{Discussion}

Eclogites in the FALC lithospheric mantle are distributed throughout the lithospheric mantle section underpinning the Sask craton. A major metasomatic event is evident that (1) primarily affected diamondiferous eclogites, (2) occurred shortly before kimberlite entrainment, as compositional heterogeneity within individual garnets is still preserved, (3) produced deviatoric stress resulting in 
diamond brecciation, and (4) took place within the diamond stability field as annealing through secondary diamond occurred. This process created strong elemental compositional gradients while acting to homogenise oxygen isotopic compositions, as expected from melt-rock interaction mass balance models (e.g.,Riches et al. 2016). A likely process could involve the intrusion and stagnation of a melt related to kimberlite magmatism near the base of the lithosphere, a process similar to the formation of polymict mantle breccias (Lawless et al. 1979; Giuliani et al. 2014).

\section{References}

Carswell DA (1975) Primary and secondary phlogopites and clinopyroxenes in garnet lherzolite xenoliths. Phys Chem Earth 9:417-429. doi: 10.1016/0079-1946(75)90031-2

Clark JR, Papike JJ (1968) Crystal-chemical characterization of omphacites. Am Mineral 53:840-868.

Collerson KD, Lewry JF, Bickford ME, Van Schmus WR (1990) Crustal evolution of the buried Precambrian of southern Saskatchewan: Implications for diamond exploration. In: Beck LS, Harper CT (eds) Modern Exploration Techniques: Saskatchewan Geological Society. pp 150165

Czas J, Pearson DG, Stachel T, Read GH, Kjarsgaard BA (submitted) Is there an Archean lithospheric mantle root beneath the Sask Craton, Canada?

Giuliani A, Phillips D, Kamenetsky VS, et al (2014) Petrogenesis of Mantle Polymict Breccias: Insights into Mantle Processes Coeval with Kimberlite Magmatism. J Petrol 55:831-858. doi: 10.1093/petrology/egu008

Harvey S, Kjarsgaard B, McClintock M, et al (2009) Geology and evaluation strategy of the Star and Orion South kimberlites, Fort à la Corne, Canada. Lithos 112:47-60. doi: 10.1016/j.lithos.2009.04.040

Hasterok D, Chapman DS (2011) Heat production and geotherms for the continental lithosphere. Earth Planet Sci Lett 307:59-70. doi: 10.1016/j.epsl.2011.04.034

Hoffman PF (1988) United Plates of America, the Birth of a Craton: Early Proterozoic Assembly and Growth of Laurentia. Annu Rev Earth Planet Sci 16:543-603.

Huang JX, Gréau Y, Griffin WL, et al (2012) Multi-stage origin of Roberts Victor eclogites: Progressive metasomatism and its isotopic effects. Lithos 142-143:161-181. doi: 10.1016/j.lithos.2012.03.002

Ickert RB, Stachel T, Stern RA, Harris JW (2013) Diamond from recycled crustal carbon documented by coupled $\delta 18 \mathrm{O}-\delta 13 \mathrm{C}$ measurements of diamonds and their inclusions. Earth Planet Sci Lett 364:85-97. doi: 10.1016/j.eps1.2013.01.008

Krogh EJ (1988) The garnet-clinopyroxene Fe-Mg geothermometer - a reinterpretation of existing experimental data. Contrib to Mineral Petrol 99:44-48. doi: 10.1007/BF00399364

Lawless PJ, Gurney JJ, Dawson JB (1979) Polymict Peridotites from the Bultfontein and de Beers Mines, Kimberly, South Africa. In: Boyd FR, Meyer HOA (eds) The Mantle Sample: Inclusions in Kimberlites and Other Volcanics. American Geophysical Union, Washington, DC, pp 144155

Leckie DA, Kjarsgaard BA, Bloch J, et al (1997) Emplacement and reworking of Cretaceous, diamond-bearing, crater facies kimberlite of central Saskatchewan, Canada. Geol Soc Am Bull 109:1000-1020. doi: 10.1130/0016-7606(1997)109<1000:EAROCD>2.3.CO;2

Rayner NM, Stern R a, Bickford ME (2005) Tectonic implications of new SHRIMP and TIMS U-Pb geochronology of rocks from the Sask Craton, Peter Lake Domain, and Hearne margin, TransHudson Orogen, Saskatchewan. Can J Earth Sci 42:635-657. doi: 10.1139/e04-045

Riches AJV, Ickert RB, Pearson DG, et al (2016) In situ oxygen-isotope, major-, and trace-element constraints on the metasomatic modification and crustal origin of a diamondiferous eclogite from Roberts Victor, Kaapvaal Craton. Geochim Cosmochim Acta 174:345-359. doi: 10.1016/j.gca.2015.11.028

Su BX, Zhang HF, Sakyi PA, et al (2011) The origin of spongy texture in minerals of mantle xenoliths from the Western Qinling, central China. Contrib to Mineral Petrol 161:465-482. doi: 10.1007/s00410-010-0543-X 